TRACKING CONDITIONAL CASH TRANSFER BENEFICIARIES

Tracking Conditional Cash Transfer Beneficiaries 
TRACKING CONDITIONAL CASH TRANSFER BENEFICIARIES

Tracking Pioneer Conditional Cash Transfer Beneficiaries using Grades and Enrollment Rate

Bernard M. Barruga*, Elreen A. Delavin, and Rocel A. Turco

Dr. Emilio B. Espinosa, Sr. Memorial State College of Agriculture and

Technology

Mandaon, Masbate, Philippines

bernbarrb@gmail.com (Bernard M. Barruga),+639095855282

delavinelreen@gmail.com, (Elreen A. Delavin)

rocelaturco74@gmail.com (Rocel A. Turco)

*Corresponding author

List of Tables/Figure:

Table 1. Age Profile of the Pioneer 4Ps Beneficiaries in Buyo, Claveria, Masbate as of their Entry in 2009

Table 2. Enrollment of the Pioneer 4Ps Beneficiaries as of their Entry in 2009

Table 3. Status of Enrollment of the Pioneer 4Ps Beneficiaries as of Present by Grade Level

Figure 1. Academic Performance of the Pioneer 4Ps Beneficiaries from SY 2010-2011 to SY 2016-2017 
TRACKING CONDITIONAL CASH TRANSFER BENEFICIARIES

\title{
Tracking Pioneer Conditional Cash Transfer Beneficiaries using Grades and Enrollment Rate
}

\begin{abstract}
Conditional cash transfer (CCT) programs have been touted to reduce poverty in developing countries. Various methods have been used to assess the effectiveness of CCT programs but little attention has been devoted to finding out whether the grantees had benefited on an individual level. This study aimed to determine the enrollment status and academic performance of the pioneer beneficiaries of the Pantawid Pamilyang Pilipino Program (4Ps), a human development program of the Philippine national government using the CCT scheme in a barangay situated in a poor municipality and province. Using data from the parent leader and from the scholastic records, it was found out that the program had a positive impact on the education of the pioneer children beneficiaries of the locality studied and it was highly successful in attaining its aim of making poor children stay in school. The study argues for the tracking of individual grantees as a measure of the CCT program's success. Due to the study's inherent limitations and exploratory nature, the following are recommended: replicate the study on a larger scale; continue tracking the pioneer as well as the other beneficiaries of the program to see whether its long-term desired outcomes are met; and study its possible negative aspects and effects. For educators handling 4Ps pupils and students, it is recommended that continuing to strictly implement compliance of family recipients with their coresponsibilities in the program is desired.
\end{abstract}

Keywords: 4Ps, academic performance, conditional cash transfer, enrollment, human capital, human development 
TRACKING CONDITIONAL CASH TRANSFER BENEFICIARIES

\section{INTRODUCTION}

One of the huge problems facing the Philippines is poverty. Masbate province is one of the country's poorest areas with a low human development index (HDI) score of 0.422 as of 2012 (Philippine Statistics Authority, 2017), way below the country's overall index value of 0.682 considered as medium human development (Human development reports, 2017). The province also has a decreasing literacy rate of $90.85 \%$ in $1990,90.78 \%$ in 1994 , and 87.23 in 2000 (Philippine Statistics Authority, 2003). It ranked third in 2003 and eighth in 2006 in poverty incidence rate with $51.0 \%$ among all the country's provinces (National Statistical Coordination Board, 2008) as cited by Gavino-Gumba (2010). In 2012, the municipality of Claveria had a poverty incidence of $52.4 \%$, third highest among the 20 municipalities and one city of the province (Philippine Statistics Authority, 2012). The province ranked ninth in the country in poverty incidence at 51.3\% (Department of Social Welfare and Development, 2014).

In the country's bid to end or decrease poverty, the Pantawid Pamilyang Pilipino Program (4Ps), formerly called Ahon Pamilyang Pilipino, was conceived as a poverty reduction strategy that provides cash assistance to extremely poor households provided they comply with certain conditions that allow the family to meet important human development goals. The program is described by the Department of Social Welfare and Development (DSWD) (2017) in its FAQ as a national human development program implemented by the DSWD in partnership with the Department of Education (DepEd), Department of Health $(\mathrm{DOH})$, and the Department of Interior and Local Government (DILG), with coordination from the local government units (LGUs). It is described as a human capital (Becker, 1993) investment to enable children who are part of poor households to have healthy growth and access to education. Household beneficiaries must comply with the conditionalities on health and education to 
receive their cash grants, which are for education: children 6-18 years old enrol in primary/ secondary schools or equivalent Alternative Learning System/ Alternative Delivery Method, and have at least 85\% school attendance; and children 3-5 years old attend daycare/ preschool program with at least 85\% school attendance. The program has since expanded to include beneficiaries to study in college.

The program was rolled out in 2008 and Masbate province belonged to the first batch of areas with 4Ps beneficiaries. Claveria municipality in the island of Burias was one of the chosen local government units (LGU's) to have target households for the program. The barangay of Buyo in the same municipality was chosen as the research area as a convenient sample where most of the researchers come from and where data may be easily available.

The results of this study are deemed important to various education stakeholders. For policy makers and implementers of the program, it is important to know whether the program has had a positive impact to the beneficiaries as can be verified from data such as their enrollment status, academic performance as seen through their average grades, and school leaving/ drop-out rates. If the impact is positive, the information is useful to guide the key decision makers and executives in their appraisal to continue, end or estimate the duration of the whole program itself. A successful poverty alleviation program must come to an end when the poverty is eradicated or brought to a minimal level. Also, it is necessary to monitor periodically the measurable short-term outcomes of the program, which may be critical to its ultimate or long-term success. The 4Ps requires a tremendous amount from the national budget and it is fair to wonder whether the money is well-spent or not.

Research data on the educational impact of the program tend to be general and it is hard to tell whether vital educational indicators such as dropout rates, 
TRACKING CONDITIONAL CASH TRANSFER BENEFICIARIES

school participation, cohort survival rates, graduation rates, and the like have been positively impacted. This exploratory study aimed to find a way to sift through the data in a detailed way. While it remains to be seen whether largescale replication of the research method employed here is financially, practically and administratively feasible, it is hoped that more capable research institutions and/ or government agencies can give it a try.

The various stakeholders such as the pupils/ students, teachers, school managers, and parents in the educative process are always benefitted whenever valuable data concerning interventions affecting their lives are made available. It helps everyone involved to understand why certain programs are implemented by the government. It is also necessary for each one to know how to fulfill his/ her responsibilities in the program.

\section{OBJECTIVES OF THE STUDY}

The objectives of the study are to determine the enrollment status and academic performance of the pioneer beneficiaries of the Pantawid Pamilyang Pilipino Program (4Ps), and to determine the impact and success of the program on the beneficiaries' education as shown by their staying or leaving school and their average grades for the school years they have spent with status as 4Ps recipients.

\section{MATERIALS AND METHODS}

\section{Research Design}

This study made use of the descriptive, quantitative, and evaluation types. Descriptive studies depict a given set of circumstances/ condition as completely and thoroughly as possible. (Fraenkel \& Wallen, 2006). This study describes the age profile, enrollment status and academic performance of the research subjects 
TRACKING CONDITIONAL CASH TRANSFER BENEFICIARIES

in the period covered. Quantitative research consists of research in which the data can be analyzed in terms of numbers. This study relied on numerical desk data gathered from the parent leader informant and from school records. Evaluation adds to the description of status the element of value judgment in terms of effectiveness, desirability, or social utility and may suggest a course of action. No generalizations are extended beyond the situation evaluated (Best \& Kahn, 2002). This study evaluated to a limited extent whether the 4Ps had a positive impact on its children-beneficiaries in the sampled barangay. No generalization that applies to the whole population of 4Ps beneficiaries in the country or even the province is stated, except in so far as to the utility of the method used and its applicability to analyze other situations. Suggested courses of action for researchers and educators are supplied in the end.

\section{Sample and Sampling Techniques}

The researchers used a purposive sample of the first set of 4Ps beneficiaries in Buyo, Claveria, Masbate. There were 51 selected beneficiaries in total.

\section{Sources of Data and Data Gathering Procedure}

Data were gathered from the records kept by a parent leader in the barangay and from the scholastic records (DepEd F-137) of the pupil beneficiaries.

\section{Statistical Tool}

Frequency count, mean and percentage were used to analyze the data.

\section{RESULTS AND DISCUSSION}

\section{The Case for Tracking Beneficiaries on an Individual Level}

CCT programs have been shown to impact poor people positively (Fiszbein \& Schady, 2009). To assess the effectiveness of the programs, evaluators often make use of experimental (random assignment), quasi-experimental (instrumental variables and regression discontinuity), and nonexperimental 
TRACKING CONDITIONAL CASH TRANSFER BENEFICIARIES

designs like regression techniques, matching, and double (or higher-order) differencing (Fiszbein \& Schady, 2009, p. 298). Different program outcomes have been studied such as education results (Behrman, Sengupta, \& Todd, Progressing through PROGRESA: An impact assessment of a school subsidy experiment in rural Mexico, 2005; de Janvry \& Sadoulet, 2006; Schultz, 2004); nutrition (Gertler, 2004; Rivera, Sotres-Alvarez, Habicht, Shamah, \& Villalpando, 2004; Behrman \& Hoddinott, 2005); and food consumption (Hoddinott \& Skoufias, 2004; Hoddinott \& Wiesmann, 2010). However, the beneficiaries are often treated as summary statistics in these cases and are often lumped together with little attention to how as to how individuals fared. According to Sayer (2005), poor people do not want simple affirmation, legitimization, and validation of their poverty but eradication of class differences or, their own individual escape from poverty itself. Education is one such avenue for rising out of poverty and access to education in itself is a factor related to poverty.

As the results of this study shows, it is possible to individually track beneficiaries' progress in academic performance and school enrollment and in later evaluations see whether poverty alleviation programs like the 4Ps can be successful in being a bridge from indigence to better human development. Having beneficiaries rise out of poverty is the concern of CCT programs but while there was success in improving the beneficiaries' level of education and formal labor market participation, the poverty or vulnerability lingered; the schooling level remained extremely low and the labor market outcomes unstable (Stampini \& Tornarolli, 2012). Seven years of schooling data in the present study revealed the modest progress of the beneficiaries at the barangay level. There must be a longitudinal tracking of these beneficiaries long after they graduate from the program. 
Age Profile and Enrollment Status of the Pioneer 4Ps Beneficiaries at the Start of the Program

Table 1

Age Profile of the Pioneer 4Ps Beneficiaries in Buyo, Claveria, Masbate as of their Entry in 2009

\begin{tabular}{lcc}
\hline Age & Frequency & Percentage \\
\hline 3 & 3 & 5.88 \\
4 & 17 & 33.33 \\
5 & 19 & 37.25 \\
6 & 12 & 23.52 \\
Total & 51 & 100.00 \\
\hline
\end{tabular}

Looking at Table 1 shows that children aged 4 and 5 were the most numerous at 17 and 19, respectively. The table also implies that the children will enter the basic education system at different times.

As of their entry to the program, the pioneers were all enrolled in the preschool or day care program. 4Ps require children 3-5 years of age to enrol in day care program or pre-school and attend at least eighty five percent $(85 \%)$ of the required school days. The beneficiaries dutifully complied with their coresponsibilities at the start of their status as such as reported in the parent leader's record. The program was successful in its aim of making the children in Buyo, Claveria, Masbate have a good start to their schooling journey. Table 2 states that all the beneficiaries were enrolled in day care program. 
TRACKING CONDITIONAL CASH TRANSFER BENEFICIARIES

Table 2

Enrollment of the Pioneer 4Ps Beneficiaries as of their Entry in 2009

\begin{tabular}{lc}
\hline $\begin{array}{l}\text { Number of Children Enrolled in Day } \\
\text { Care Program }\end{array}$ & $\begin{array}{l}\text { Number of Children Not } \\
\text { Enrolled in Day Care Program }\end{array}$ \\
\hline 51 & 0 \\
\hline
\end{tabular}

\section{Enrollment Status of the Pioneer 4Ps Beneficiaries at Present}

On Table 3, the status of enrollment as of School Year 2017-2018 is shown. Comparing the data with Table 2, it is shown that indeed, the children entered the basic education system at different times as shown by their different grade levels, owing to their age differences in the first place. Out of the initial 51 beneficiaries tracked in 2009, only one did not continue schooling while two had dropped out at some point but later returned to school as shown on Table 4 . 
TRACKING CONDITIONAL CASH TRANSFER BENEFICIARIES

Table 3

Status of Enrollment of the Pioneer 4Ps Beneficiaries as of Present by Grade Level

\begin{tabular}{lcc}
\hline Year Level & $\begin{array}{c}\text { Total Number Enrolled in } \\
\text { School }\end{array}$ & Percentage \\
\hline Grade 4 & 8 & 15.68 \\
Grade 5 & 5 & 9.8 \\
Grade 6 & 35 & 68.62 \\
Grade 6 & 2 & 3.92 \\
\hline Total & 51 & 100.00 \\
\hline
\end{tabular}

Poverty, as observed in Masbate, is more likely to lead to low elementary and secondary participation rates, low elementary and secondary cohort survival rates, and high illiteracy rates, among other effects (Gavino-Gumba, 2010). The province's consistent placing among the poorest in the entire country is likely one of the reasons it was chosen as a pioneer recipient of the 4Ps. In a study of an impoverished community inside the campus of the lone state college in the province, the poor people's vulnerability to almost all types of risks was revealed (Lamela, Lamela, Buayan, \& Malto, 2014). In the present findings, data on enrollment and continuity of schooling show how a human development program and human capital investment (Lauder, 2014; Gillies, 2017) in the form of CCT can be a potential instrument in arresting the vicious cycle of poverty. Education is one avenue for social mobility, enabling people to escape the cruel recurrence of ignorance leading to poverty and vice versa. 
TRACKING CONDITIONAL CASH TRANSFER BENEFICIARIES

Table 4

Present Status of Enrollment of the Pioneer 4Ps Beneficiaries according to Continuity of Schooling

\section{Total Number}

\begin{tabular}{lcc} 
Status & $\begin{array}{c}\text { Enrolled in } \\
\text { School }\end{array}$ & Percentage \\
\hline $\begin{array}{lcc}\text { Currently enrolled with continuous } \\
\text { schooling }\end{array}$ & 48 & 94.12 \\
$\begin{array}{l}\text { Currently not enrolled } \\
\text { Currently enrolled but who have }\end{array}$ & 1 & 1.96 \\
stopped at some point & 2 & 3.92 \\
\hline Total & 51 & 100.00
\end{tabular}

The total number who have left school (1 or 1.96) among the beneficiaries from the start up to the present is better than the national average dropout rate of $6.02 \%, 6.28 \%, 6.29 \%$ and $6.38 \%$ from SY 2008-2009 to SY 2011-2012 (Department of Education, 2013), even adding the 3.92\% returnees still adds up to just $5.88 \%$. The yearly dropout rates for the beneficiaries would be even lower though the present analysis did not compute for these. It can be said that the 4Ps beneficiaries of the locale of the study as a group did better than the national average. Hence, one of the conditionalities of the program which is to address the high dropout rate was at least fulfilled in the sample barangay. However, no comparison was made with similarly poor pupil/ student groups who were not 4Ps beneficiaries.

\section{Academic Performance of the Pioneer 4Ps Beneficiaries}

In terms of academic performance, the pioneer 4Ps beneficiaries showed a flat trend in the first four years (a low of 78.37 and a high of 78.62 or a difference 
TRACKING CONDITIONAL CASH TRANSFER BENEFICIARIES

of 0.25), a full one-point decline in SY 2014-2015 (78.62 to 77.62) and an average of more than one point increases in the last two years (79.50 and 80.45). Using the DepEd's descriptive rating equivalents, the beneficiaries had Developing (ratings of 75-79) levels in the first four school years and when rounded off, Approaching Proficiency (ratings of 80-84) levels in the last two years. The recent increase and leap in proficiency level are notable. Overall, there an average increase of 0.31 for the six school years. Making sense of the results by comparing them with the results of other studies such as Montilla, Delavin, Villanueva, and Turco (2015) and Paqueo, Orbeta, Castaneda, and Spohr (2013), which reported positive impact on the education of the beneficiaries, the present study's findings jive with the prior studies' findings as to the efficacy of the 4Ps in the short term.

The long view is that the 4Ps is an investment in human capital. According to Becker (1993), the income of a person is a function of the amount of investment in human capital. On a larger scale, an extensive investment in human capital is an essential element of economic growth (Human-capital theory, 1998). The hope is that this lead ultimately to full human development, as measured by the United Nations in three key dimensions: a long and healthy life, access to knowledge and a decent standard of living. The HDI is the geometric mean of normalized indices for each of the three dimensions. (United Nations, 2016).

Possible explanations why the 4Ps can be effective is found in Montilla, Delavin, Villanueva, \& Turco (2015). The program was credited with having a significant impact on pupils' education by making them be present in school through the program's extrinsic motivations. On a macro-scale, 4Ps was beneficial economically and socially (Paqueo, Orbeta, Castaneda, \& Spohr, 2013). 
TRACKING CONDITIONAL CASH TRANSFER BENEFICIARIES

On the national level, the 4Ps is described as a valuable program to prevent the poor from being mired forever in poverty through human capital investment although it was cautioned that in isolation, it is not adequate, in so short a time, to reduce poverty (Albert, Dumagan, \& Martinez, 2015). The program is therefore not designed to be a cure-all for the ills afflicting the Filipino poor. When the program was first envisioned, it was targeted to last for only five years, meaning, it should have terminated in 2013 for the first set of beneficiaries. In arguing for its extension beyond the initial five-year limit, Paqueo, Orbeta, Castaneda, and Spohr (2013) pointed out the Pantawid extension's economic and social benefits. 


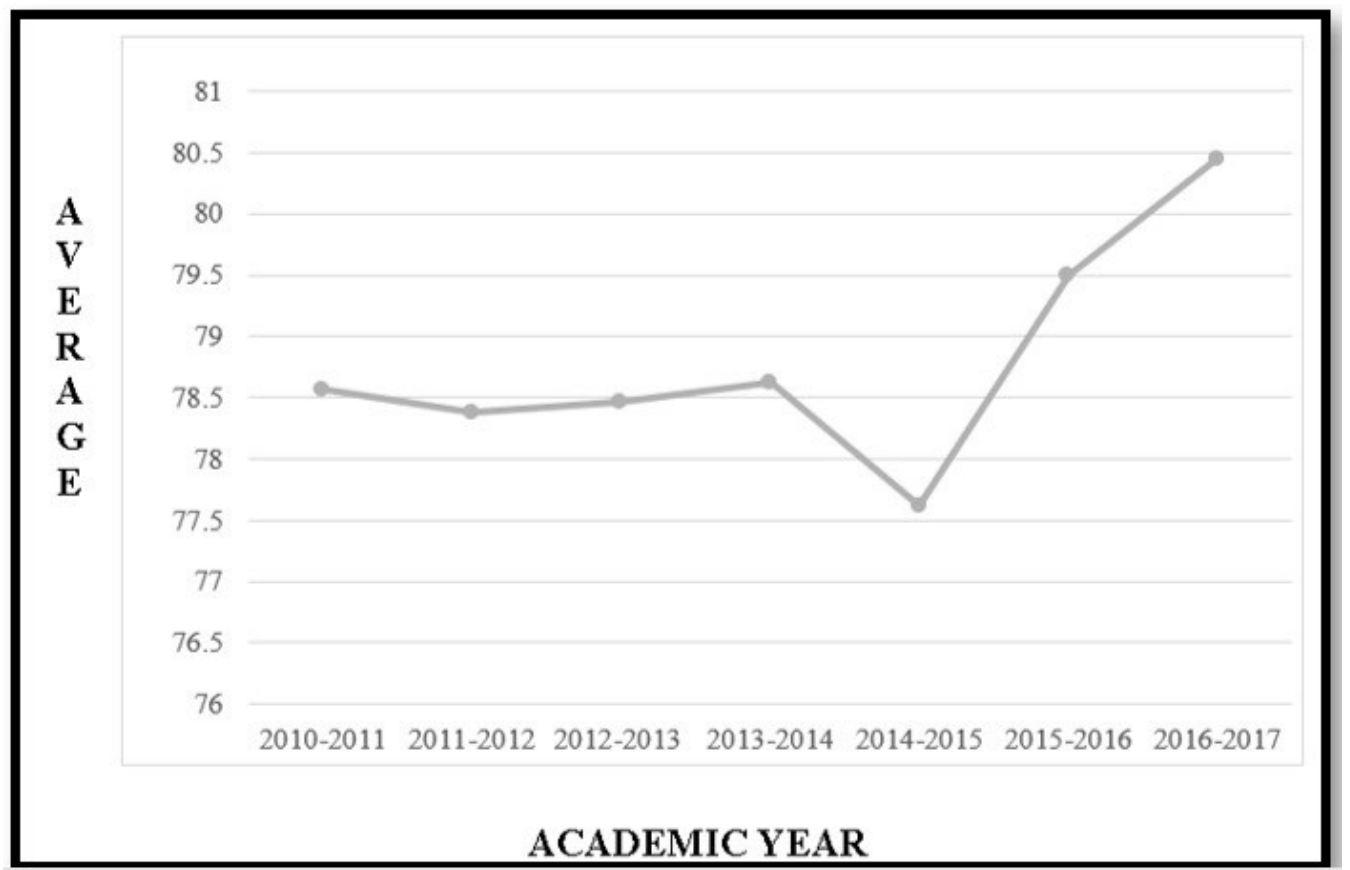

Figure 1. Academic Performance of the Pioneer 4Ps Beneficiaries from SY 2010-2011 to SY 2016-2017

\section{CONClusions}

The 4Ps had a positive impact on the education of the pioneer children beneficiaries of the locality studied and it was highly successful in attaining its aim of making poor children stay in school, at least in the sampled barangay and up to the time covered. In general, conditional cash transfer (CCT) programs have been shown to help in development, primarily through effecting positive change in the lives of the poor (Fiszbein \& Schady, 2009). Different program outcomes have been studied such as education results (Behrman et al., 2005; de Janvry \& Sadoulet, 2006; Schultz, 2004); and nutrition outcomes (Behrman et al., 2005; Gertler, 2004; Rivera et al., 2004). The present study contributes to the two 
TRACKING CONDITIONAL CASH TRANSFER BENEFICIARIES

theories of human capital and human development by offering short term evidence of the efficacy of a government program in achieving human capital investment and eventually improvement of poor people's lives.

Due to the study's inherent limitations and exploratory nature, the following are recommended: replicate the study on a larger scale; continue tracking the pioneer as well as the other beneficiaries of the program to see whether its long-term desired outcomes are met; and study its possible negative aspects and effects. For educators handling 4Ps pupils and students, it is recommended that continuing to strictly implement compliance of family recipients with their co-responsibilities in the program is desired.

\section{ACKNOWLEDGMENT}

The authors would like to thank their students Niezel C. Gerarman, Aiza R. Alfornon, Jevelyn R. Bahayan, and Christy Ann Olayres for gathering the data used in this article.

\section{REFERENCES}

Albert, J. R., Dumagan, J. C., \& Martinez, A. J. (2015, January). Inequalities in income, labor, and education: The challenge of inclusive growth. PIDS Discussion Paper Series. Philippine Institute for Development Studies.

Becker, G. S. (1993). Human capital: A theoretical and empirical analysis with special reference to education. University of Chicago Press.

Behrman, J. R., \& Hoddinott, J. (2005). Programme evaluation with unobserved heterogeneity and selective implementation: The Mexican PROGRESA impact on child nutrition. Oxford Bulletin of Economics and Statistics, 67(4), 547-569. doi:https://doi.org/10.1111/j.1468-0084.2005.00131.x

Behrman, J. R., Sengupta, P., \& Todd, P. (2005). Progressing through PROGRESA: An impact assessment of a school subsidy experiment in 
TRACKING CONDITIONAL CASH TRANSFER BENEFICIARIES

rural Mexico. Economic Development and Cultural Change, 54(1), 237-275. doi:https://doi.org/10.1086/431263

Best, J. W., \& Kahn, J. V. (2002). Research in education. New Jersey: Allyn and Bacon.

de Janvry, A., \& Sadoulet, E. (2006). Making conditional cash transfers more efficient: Designing for maximum effect of the conditionality. World Bank Economic Review, 20(1), 1-29. doi:https://doi.org/10.1093/wber/lhj002

Department of Education. (2013, October 25). Basic education statistics Department of Education. Retrieved October 31, 2017, from Department of Education Web site: http://www.deped.gov.ph/sites/default/files/datasets/2013/factsheetOct $\% 2025 \% 202013$.xls

Department of Social Welfare and Development. (2014). Poverty map. Retrieved from Department of Social Welfare and Development web site: http://data.dswd.gov.ph/wp-content/uploads/2014/09/Poverty-MapHPI-final.png

Department of Social Welfare and Development. (2017). Pantawidfaq. Retrieved October 31, 2017, from Department of Social Welfare and Development Web site:

http://pantawid.dswd.gov.ph/images/stories/pantawidfaq.pdf

Fiszbein, A., \& Schady, N. (2009). Conditional cash transfers: Reducing present and future poverty. Washington, DC: World Bank.

Fraenkel, J. R., \& Wallen, N. E. (2006). How to design and evaluate research in education (6th ed.). Boston, MA: McGraw-Hill.

Gavino-Gumba, B. M. (2010). The social and economic dimensions of rural poverty in the province of Masbate. 11th National Convention on Statistics (NCS). Retrieved from http://nap.psa.gov.ph/ncs/11thNCS/papers/invited\%20papers/ips17/02_The \%20Social\%20and\%20Economic\%20Dimensions\%20of $\% 20$ Rural\%20Poverty\%20in\%20the\%20Province\%20of\%20Masbate.pdf

Gertler, P. (2004). Do conditional cash transfers improve child health? Evidence from PROGRESA's control randomized experiment. 
TRACKING CONDITIONAL CASH TRANSFER BENEFICIARIES

American Economic Review, 94(2), 336-341.

doi:https://doi.org/10.1257/0002828041302109

Gillies, D. (2017). Human capital theory in education. In M. E. Peters (Ed.), Encyclopedia of educational philosophyand theory (pp. 1053-1057). Singapore: Springer.

Hoddinott, J., \& Skoufias, E. (2004). The impact of PROGRESA on food consumption. Economic Development and Cultural Change, 53(1), 3761. doi:https://doi.org/10.1086/423252

Hoddinott, J., \& Wiesmann, D. (2010). The impact of conditional cash transfer programs on food consumption. In M. Rdato, \& J. Hoddinott (Eds.), Conditional cash transfers in Latin America (pp. 258-283). Baltimore, MD: Johns Hopkins University Press. doi:http://dx.doi.org/10.2139/ssrn.1269417

Human development reports. (2017). Retrieved from United Nations Development Programme Web site: http:/hdr.undp.org/en/composite/HDI

Human-capital theory. (1998). In A dictionary of sociology. Oxford: Oxford University Press. Retrieved October 30, 2017, from http://www.encyclopedia.com/social-sciences/dictionaries-thesaurusespictures-and-press-releases/human-capital-theory

Lamela, R. A., Lamela, D. L., Buayan, M. C., \& Malto, E. H. (2014, August). Mitigating hunger among Tipon-tipon families: A case of self-help. DEBESMSCAT R\&D Journal, 3(1), 1-4.

Lauder, H. (2014). Economic development and education. In D. C. Phillips (Ed.), Encyclopedia of educational philosophy and theory (pp. 249252). SAGE.

Montilla, M. M., Delavin, E. A., Villanueva, R. J., \& Turco, R. A. (2015, July ). Pantawid Pamilyang Pilipino Program (4Ps): Assistance to pupil's education. Asia Pacific Journal of Education, Arts and Sciences, 2(3).

National Statistical Coordination Board. (2008). Retrieved from http://www.nscb.gov.ph 
TRACKING CONDITIONAL CASH TRANSFER BENEFICIARIES

Paqueo, V., Orbeta, A., Castaneda, T., \& Spohr, C. (2013, August). After five years of Pantawid, what next? PIDS Discussion Paper Series. Philippine Institute for Development Studies.

Philippine Statistics Authority. (2003). Retrieved from Philippine Statistics Authority: https://psa.gov.ph/sites/default/files/MASBATE.pdf

Philippine Statistics Authority. (2012). Retrieved from Philippine Statistics Authority web site: http://psa.gov.ph/sites/default/files/2012\%20SAE_final_1.xlsx

Philippine Statistics Authority. (2017). Quickstat Masbate. Retrieved October 30, 2017, from Philippine Statistics Authority Web site: https://psa.gov.ph/sites/default/files/attachments/ird/quickstat/Masbate_ 49.xls

Rivera, J. A., Sotres-Alvarez, D., Habicht, J., Shamah, T., \& Villalpando, S. (2004). Impact of the Mexican Program for Education, Health, and Nutrition (Progresa) on rates of growth and anemia in infants and young children. Journal of American Medical Association, 291(21), 25632570. doi:https://doi.org/10.1001/jama.291.21.2563

Sayer, A. (2005). The moral significance of class. Cambridge: Cambridge University Press.

Schultz, T. P. (2004). School subsidies for the poor: Evaluating the Mexican PROGRESA poverty program. Journal of Development Economics, 74(1), 199-250. doi:https://doi.org/10.1016/j.jdeveco.2003.12.009

Stampini, M., \& Tornarolli, L. (2012). The growth of conditional cash transfers in Latin America and the Caribbean: Did they go too far? Bonn, Germany: Institute for the Study of Labor. Retrieved from www.econstor.eu/bitstream/10419/91737/1/pp49.pdf

United Nations. (2016). Human development report 2016 technical notes. Retrieved from United Nations Human Development Reports: http://hdr.undp.org/sites/default/files/hdr2016_technical_notes.pdf 